\title{
PENINGKATAN PRODUKTIVITAS BUBU APUNG DENGAN LAMA PERENDAMAN YANG BERBEDA TERHADAP HASIL TANGKAPAN
}

\author{
Increasing Productivity of Floating Trap with Different Immersion Time Towards Fish Catch \\ Oleh: \\ Ladestam Sitinjak $^{1 *}$, Risma Mariva Tua Lumban Gaol ${ }^{1}$, Juni Susanti Banurea ${ }^{1}$ \\ ${ }^{1}$ Program Studi Pemanfaatan Sumberdaya Perikanan, \\ Sekolah Tinggi Perikanan Sibolga, Sibolga, Indonesia \\ *Korespondensi penulis: ladestamsitinjak@stpsibolga.ac.id
}

\begin{abstract}
ABSTRAK
Hasil tangkapan dengan menggunakan bubu dasar masih tergolong rendah dan tidak ramah lingkungan karena dapat merusak terumbu karang. Untuk itu dilakukan penelitian ini yang bertujuan untuk meningkatkan produktivitas bubu apung serta mengetahui waktu dan lama perendaman bubu yang terbaik. Penelitian ini dilaksanakan dengan metode eksperimental yang didesain dengan menggunakan Rancangan Acak Kelompok (RAK). Hasil tangkapan paling banyak pada bubu apung dengan lama perendaman 6 hari yaitu sebanyak 15 ekor, jenis ikan adalah ikan baronang, ikan tanda, dan ikan jarang gigi.
\end{abstract}

Kata kunci: bubu apung, hasil tangkapan, lama perendaman, produktivitas

\begin{abstract}
The catch using bottom traps is still low and not environmentally friendly because it can damage coral reefs. For this reason, this research was carried out with the aim of increasing the productivity of floating traps and find out the best time and duration of soaking the bubu. This research was carried out using an experimental method which was designed using a completely randomized design (CRD). Most of the catches were caught in floating traps with 6 days of soaking time, which was 15 fish.
\end{abstract}

Key words: fish catch, floating trap, productivity, soaking time

\section{PENDAHULUAN}

Indonesia memiliki sumber daya hayati seperti ikan, terumbu karang, padang lamun, mangrove dan biota laut lainnya (PERMEN KP Nomor 26 2021). Besarnya potensi sumber daya hayati tersebut seharusnya menghasilkan hasil tangkapan yang besar. Sementara itu, tangkapan nasional masih dicirikan oleh tangkapan skala kecil (Aslan dan Nadia 2010). Perikanan tangkap skala kecil adalah perikanan yang menyediakan mata pencaharian dan ketahanan pangan bagi jutaan nelayan skala-kecil dan masyarakat lokal di berbagai penjuru dunia. Perikanan skala-kecil menghasilkan ikan hanya untuk dikonsumsi manusia. Bubu merupakan alat tangkap yang umum digunakan untuk menangkap jenisjenis ikan terumbu karang di Perairan Teluk Tapanuli. Sesuai hasil penelitian Daeli et al. (2020), selama periode 2016-2018, produktivitas bubu terus mengalami penurunan seiring semakin banyaknya alat tangkap yang salah digunakan.

Von Brandt (2005) menyatakan bahwa bubu adalah jebakan yang biasa dikenal oleh nelayan dan merupakan salah satu jenis alat tangkap pasif. Bubu biasanya dioperasikan di dasar perairan. Bubu dapat beroperasi di daerah yang tidak dapat dioperasikan oleh jenis alat tangkap lainnya, seperti daerah berbatu, celah-celah karang, lubang sela bebatuan, perairan yang sangat dalam, dan perairan dengan pantai berbentuk tebing yang tinggi dan curam (Puspito 2009). Bubu apung adalah perangkap yang 
tidak bersentuhan langsung dengan dasar air dan tidak merusak karang. Karang merupakan biota laut yang tersebar luas oleh masyarakat (Sitinjak et al. 2021) dan tidak mempengaruhi karang. Setelah itu, dapat dioperasikan oleh satu atau dua orang. Selain itu, alat tangkap bubu ini mudah dikendalikan karena kedalamannya hanya 1-2 meter di bawah rakit. Ikan pelagis dapat ditangkap dengan alat tangkap pasif floating trap (Noer 2011).

Banyak faktor yang mempengaruhi penangkapan dengan bubu apung, seperti waktu perendaman, tingkat kejenuhan alat, habitat, desain bubu, dan penggunaan umpan (Isnawati et al. 2020). Martasuganda (2008), semua jenis perangkap bekerja dengan cara yang hampir sama. Dengan kata lain, selain daerah penangkapan ikan yang diperkirakan memiliki banyak ikan. Beberapa perangkap dipasang secara individual (instalasi sistem tunggal) dan lainnya dipasang dalam rantai (instalasi sistem longline). Waktu pemasangan (installation) dan pengangkatan (transportasi) adalah pagi, siang dan sore hari. Menurut Noer (2011), perendaman selama tiga hari, empat hari dan lima hari memiliki efek yang berbeda pada tangkapan.

Hasil penelitian ini diharapkan dapat memberi dampak yang bermanfaat secara akademik dan praktis yaitu memberikan penyuluhan berupa seminar kepada nelayan, petani dan pelaku usaha perikanan tentang kegiatan perikanan tangkap dengan harapan para nelayan dapat menggunakan bubu apung menjadi alat tangkap alternatif untuk mendapatkan hasil tangkapan yang maksimal dan ramah lingkungan, memberi sumbangsih terhadap perkembangan ilmu pengetahuan berupa publikasi jurnal ilmiah terakreditasi SINTA, kebaruan dari penelitian ini adalah pemanfaatan bubu apung dengan lama perendaman yang berbeda di Teluk Tapian Nauli.

\section{METODE PENELITIAN}

Survei dilakukan di Teluk Tapian Nouli dari 11 Januari hingga 30 Oktober 2021. Pengumpulan data dilakukan dengan metode eksperimen, wawancara, dan studi kepustakaan. Penelitian ini dilakukan pada pembuatan bubu apung dengan menggunakan atraktor yang berbeda, dan penelitian selanjutnya memperlakukan bubu dengan tiga jenis waktu perendaman yang berbeda.

Data yang diperlukan untuk penelitian ini adalah berbagai perlakuan perendaman bubu, yaitu hasil tangkapan 2 hari, 4 hari, dan 6 hari. Bubu apung memiliki bentuk dan ukuran yang sama dan ditempatkan pada lokasi yang sama untuk setiap perlakuan. Hal ini didukung oleh pernyataan Kesaulya et al. (2015) bahwa bubu memiliki banyak bentuk dan ukuran dalam perkembangannya. Jenis ikan sasarannya berbeda-beda. Data awal yang sebelum penelitian meliputi kondisi substrat air, kedalaman dan kecerahan perairan. Daerah yang digunakan alat tangkap merupakan daerah yang subur, dan kesuburan air dapat mempengaruhi kelimpahan makanan (Munirma et al. 2020). Daerah yang subur memiliki kriteria tingginya produktivitas primer, misalnya fitoplankton.

Data yang dibutuhkan selama penelitian dari tiga perlakuan dan tiga daerah penangkapan ikan (DPI) adalah hasil tangkapan berupa parameter bobot dan panjang ikan, yang diperoleh dengan menggunakan metode experimental fishing, selanjutnya data tersebut dianalisis dengan menggunakan metode Analisis of Varian (ANOVA) dengan menggunakan model Rancangan Acak Kelompok (RAK). Ditampilkan dalam bentuk ANOVA dan Histogram sebagai berikut (Sudjana 2018).

$$
Y i j=\mu+\tau i+\beta j+\varepsilon i j
$$

Keterangan :

Yij = Nilai pengamatan pada perlakuan ke lama perendaman dan kelompok ke DPI "Daerah Penangkapan Ikan“

$\mu \quad=$ Nilai tengah perlakuan

$\tau \mathrm{i} \quad=$ Pengaruh lama perendaman bubu apung

$\beta \mathrm{j} \quad=$ Pengaruh daerah penangkapan ikan (DPI)

$€ \mathrm{ij}$ = Pengaruh galat percobaan lama perendaman dan daerah penangkapan ikan (human error) 
i = Jumlah lama perendaman bubu apung (2 Hari, 4 Hari, 6 hari)

$\mathrm{j} \quad=$ Kelompok daerah penangkapan ikan dari setiap perlakuan $(1,2,3)$

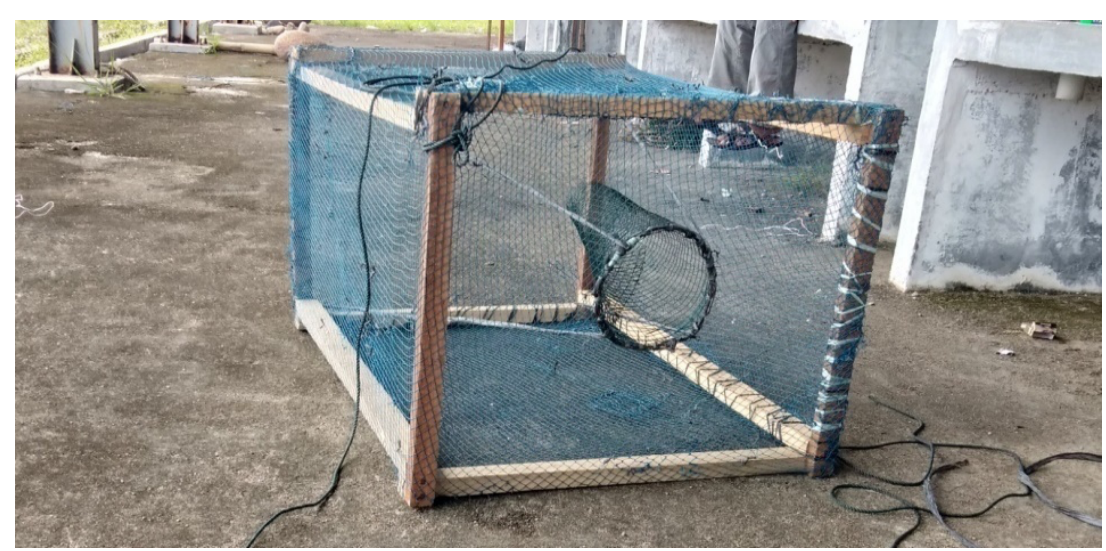

Gambar 1 Alat tangkap bubu apung

Bubu apung yang digunakan dalam penelitian ini ada sebanyak 3 untuk setiap daerah penangkapan yang berarti dalam penelitian ini membutuhkan 9 bubu apung. Parameter yang diukur adalah panjang dan bobot ikan. Spesifikasi ukuran alat tangkap bubu apung yang digunakan selama penelitian dapat dilihat pada Tabel 1.

Tabel 1 Dimensi bubu apung yang digunakan selama penelitian

\begin{tabular}{lll}
\hline No & \multicolumn{1}{c}{ Uraian } & \multicolumn{1}{c}{ Keterangan } \\
\hline 1. & Bahan selimut bubu & jaring bahan monofilament \\
2. & Mesh size jaring & 1 inchi \\
3. & Bentuk bubu & persegi panjang \\
4. & Ukuran bubu & $\mathrm{p}=100 \mathrm{~cm}, 1=70, \mathrm{t}=60$ \\
5. & Jumlah bubu & 3 unit, $\mathrm{p} 1=2$ hari, $\mathrm{p} 2=4$ hari, $\mathrm{p} 3=6$ hari. \\
6. & Rangka Bubu & kayu ukuran $5 \times 7$ \\
7. & Diameter mulut bagian luar & $70 \mathrm{~cm}$ \\
8. & Diameter mulut bagian dalam & $30 \mathrm{~cm}$ \\
9. & Panjang mulut bubu & $50 \mathrm{~cm}$ \\
10. & Pelampung tanda & bambu \\
11. & Tali nylon & ukuran 5 \\
12. & Pemberat & batu dengan berat $10 \mathrm{~kg}$ \\
\hline
\end{tabular}

Alat dan bahan Penelitian yang digunakan dapat dilihat ada Tabel 2.

Tabel 2 Alat dan bahan

\begin{tabular}{lll}
\hline No. & Nama Alat & \multicolumn{1}{c}{ Fungsi } \\
\hline 1. & Bubu apung & sebagai alat perlakuan \\
2. & Styrofoam & sebagai tempat hasil tangkapan \\
3. & GPS & alat penentu titik koordinat \\
4. & Pulpen \& Buku & untuk mencatat hasil data peneltian \\
5. & Tali nylon & sebagai pemikat bubu dan pelampung \\
6. & kamera & sebagai alat dokumentasi \\
7. & Batu & sebagai pemberat \\
8. & Ikan rucah (ikan layang) & sebagai pemikat perhatian ikan \\
\hline
\end{tabular}




\section{Letak Daerah Labuhan Angin}

Labuhan Angin merupakan salah satu daerah yang berada di sekitar wilayah Pangkalan Pendaratan Ikan (PPI), secara administrasi daerah ini merupakan daerah perairan Kabupaten Tapanuli Tengah. Secara geografis terletak pada wilayah pengembangan pantai barat Sumatera Utara serta memiliki topografi, kontur dan iklim yang relatif datar di bagian selatan dan berbukit di bagian utara. Wilayah kawasan Labuhan Angin substratnya berlumpur hanya sebagian wilayah yang memang substratnya berkarang, selain itu keadaan perairannya tenang yang memiliki kedalaman perairan 5-8 meter.

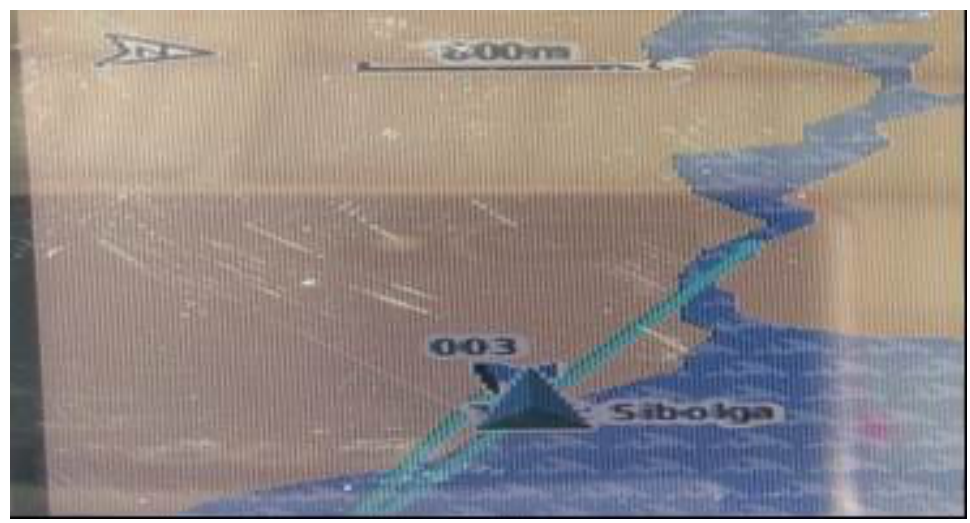

Gambar 2 Daerah Labuhan Angin

\section{Daerah Pengoperasian Bubu Apung}

Nelayan bubu di Pantai Barat Sumatera memiliki daerah pengoperasian bubu yang cukup luas. Labuhan Angin merupakan daerah perairan terletak pada N 01.766150 dan E 098.704650 dengan topografi substrat lumpur dan berkarang dengan kedalaman 5-8 meter. Bubu apung selama penelitian dioperasikan di Perairan Labuhan Angin, Kabupaten Tapanuli Tengah, di mana dasar perairannya berlumpur dengan kedalaman perairan 4,5 meter, alat tangkap dioperasikan dengan kedalaman 2 meter dari permukaan perairan, serta jarak antara bubu dengan bubu yang lain 15 meter dengan panjang tali pelampung 2,5 meter. Lokasi/daerah pengoperasian alat tangkap dapat dilihat pada Gambar 3.

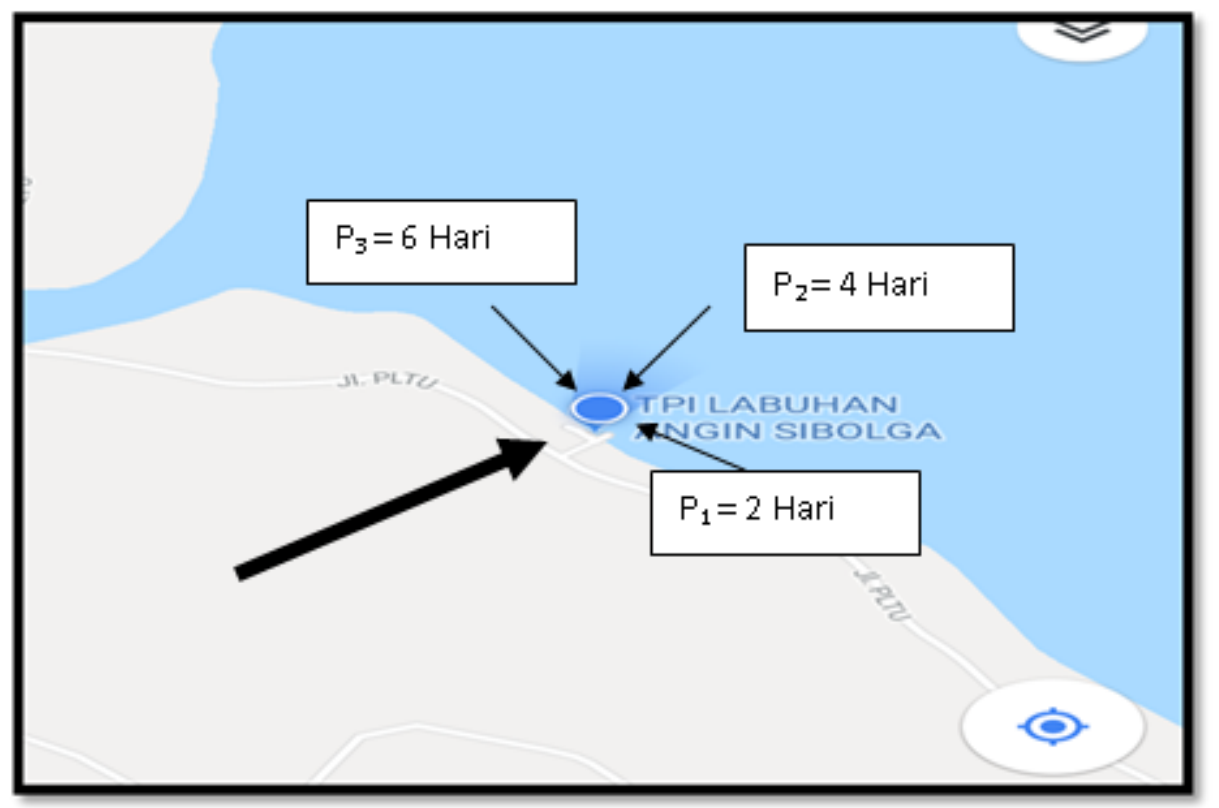

Gambar 3 Lokasi pengoperasian bubu apung 


\section{HASIL DAN PEMBAHASAN}

\section{Teknik Pengoperasian Bubu Apung} lain:

Pengoperasian alat tangkap bubu apung saat penelitian dibagi menjadi beberapa tahap antara

1. Tahap persiapan sebelum penurunan bubu (pra-setting)

2. Tahap penurunan bubu (setting)

3. Tahap perendaman (soaking)

4. Tahap Pengangkatan atau penarikan bubu (hauling)

\section{Penurunan Bubu (setting)}

Jadwal penurunan bubu (setting) dan penarikan bubu (hauling) dapat dilihat pada Tabel 3.

Tabel 3 Jadwal penurunan bubu

\begin{tabular}{lccc}
\hline \multicolumn{4}{c}{ Daerah Penangkapan Ikan (DPI) } \\
\hline Perlakuan & DP 1 & DP 2 & DP 3 \\
\hline P1 (2 hari) & Kamis, 04 April 2021 & Rabu, 05 Mei 2021 & Senin, 07 Juni 2021 \\
P2 (4 hari) & Kamis, 04 April 2021 & Rabu, 05 Mei 2021 & Senin, 07 Juni 2021 \\
P3 (6 hari) & Kamis, 04 April 2021 & Rabu, 05 Mei 2021 & Senin, 07 Juni 2021 \\
\hline
\end{tabular}

\section{Penarikan bubu (hauling)}

Tabel 4 Jadwal penarikan bubu

\begin{tabular}{llll}
\hline \multicolumn{4}{c}{ Derah Penangkapan Ikan (DPI) } \\
\hline Perlakuan & \multicolumn{1}{c}{ DP 1 } & \multicolumn{1}{c}{ DP 2 } & DP 3 \\
\hline P1 (2 hari) & Selasa, 06 April 2021 & Jumat, 07 Mei 2021 & Rabu, 09 Juni 2021 \\
P2 (4 hari) & Kamis, 08 April 2021 & Minggu, 09 Mei 2021 & Jumat, 11 Juni 2021 \\
P3 (6 hari) & Sabtu, 10 April 2021 & Selasa, 11 Mei 2021 & Minggu, 13 Juni 2021 \\
\hline
\end{tabular}

\section{Hasil Tangkapan Bubu Apung}

Penelitian ini dilakukan selama \pm 3 bulan di perairan Labuhan Angin, Tapanuli Tengah. Pengoperasian bubu apung dengan lama perendaman yang berbeda, dari hasil tangkapan terdapat beberapa jumlah ikan pada masing-masing unit percobaan. Jenis ikan yang tertangkap pada alat tangkap bubu ini merupakan ikan pelagis dan demersal (Hefraris 2020), antara lain ikan tanda (Lutjanus mahogoni), ikan baronang (Siganus sp.), ikan jarang gigi/jambian (Lutjanus argentimaculatus).

Tabel 5 Jenis-jenis dan bobot ikan yang tertangkap pada bubu apung

\begin{tabular}{|c|c|c|c|}
\hline Nama Daerah & Nama Indonesia & Nama Latin & Bobot (gram) \\
\hline Ikan Tando-tando & Ikan Tanda & Lutjanus mahogoni & 1500 \\
\hline Cabe-cabe & Baronang & Siganus sp. & 600 \\
\hline Jarang gigi & Jambian/Jarang gigi & Lutjanus argentimaculatus & 120 \\
\hline
\end{tabular}

Jumlah hasil tangkapan bubu yang diperoleh dalam tiga perlakuan dan tiga daerah penangkapan yang berbeda berjumlah 37 ekor dengan 3 jenis ikan antara lain ikan tanda, ikan baronang, ikan jarang gigi. Bubu apung dengan lama perendaman 2 hari dari tiga daerah penangkapan ikan memperoleh hasil tangkapan dengan jumlah 10 ekor. Sementara itu, bubu apung dengan lama perendaman 4 hari dari tiga daerah penangkapan ikan memperoleh hasil tangkapan dengan jumlah 12 ekor dan bubu apung dengan lama perendaman 6 hari dari tiga daerah penangkapan ikan memperoleh hasil tangkapan dengan jumlah 15 ekor. 
Jumlah individu ikan dari hasil tangkapan bubu apung yang didapatkan selama melakukan penelitian tertuang pada Tabel 6. Hal ini bertentangan dengan pendapat Setiyono (2016) yang menyatakan bahwa lama perendaman 5 hari memperoleh hasil tangkapan yang lebih banyak dengan lama perendaman 3 hari, 6 hari maupun 7 hari.

Tabel 6 menunjukkan jumlah individu ikan dari hasil tangkapan bubu yang diperoleh selama penelitian. Hal ini berbeda dengan pendapat Setiyono (2016) bahwa lama perendaman 5 hari lebih produktif dari pada perendaman 3 hari, 6 hari, dan 7 hari.

Tabel 6 Komposisi dan bobot hasil tangkapan bubu apung

\begin{tabular}{|c|c|c|c|c|c|}
\hline \multirow{2}{*}{ Perlakuan } & \multirow{2}{*}{ Jenis Ikan } & \multicolumn{3}{|c|}{ Komposisi Jenis dan Bobot Hasil Tangkapan } & \multirow{2}{*}{ Jumlah } \\
\hline & & DP 1 (bobot) & DP 2 (bobot) & DP 3 (bobot) & \\
\hline \multirow[t]{3}{*}{2 hari } & Ikan Tanda & 2 ekor (135 gram) & 2 ekor (150 gram) & 3 ekor (190 gram) & \\
\hline & Baronang & 2 ekor (95 gram) & 2 ekor (60 gram) & 0 & 10 ekor \\
\hline & Jarang gigi & 0 & 0 & 0 & \\
\hline \multirow[t]{3}{*}{4 hari } & Ikan Tanda & 2 ekor (90 gram) & 3 ekor (160 gram) & 2 ekor (140 gram) & \\
\hline & Baronang & 2 ekor (130 gram) & 2 ekor (120 gram) & 1 ekor (80 gram) & 13 ekor \\
\hline & Jarang gigi & 0 & 0 & 1 ekor (70 gram) & \\
\hline \multirow[t]{3}{*}{6 hari } & Ikan Tanda & 3 ekor (150 gram) & 4 ekor (380 gram) & 4 ekor (355 gram) & \\
\hline & Baronang & 1 ekor (60 gram) & 1 ekor (70 gram) & 0 & 14 ekor \\
\hline & Jarang gigi & 1 ekor (50 gram) & 0 & 0 & \\
\hline
\end{tabular}

Tabel di atas menunjukkan bahwa pengoperasian bubu apung dengan 6 hari lama perendaman menunjukkan bobot hasil tangkapan paling tinggi dengan bobot 1070 gram sedangkan pada lama perendaman 4 hari memperoleh bobot hasil tangkapan 790 gram dan pada lama perendaman 2 hari memperoleh bobot hasil tangkapan 630 gram. Penyebaran hasil tangkapan bubu ini diperoleh dari 3 daerah penangkapan ikan untuk masing-masing perlakuan. Hal ini senada dengan penelitian Isnawati et al. (2020) yang menyatakan bahwa pengaruh lama perendaman terhadap jumlah dan berat ikan yang tertangkap berpengaruh sangat nyata dengan nilai signifikansi 0,007.

Berdasarkan hasil tangkapan ikan pada perlakuan dan ulangan, maka jumlah rata-rata ikan hasil tangkapan bubu apung setiap perlakuan dapat kita lihat pada histogram berikut:

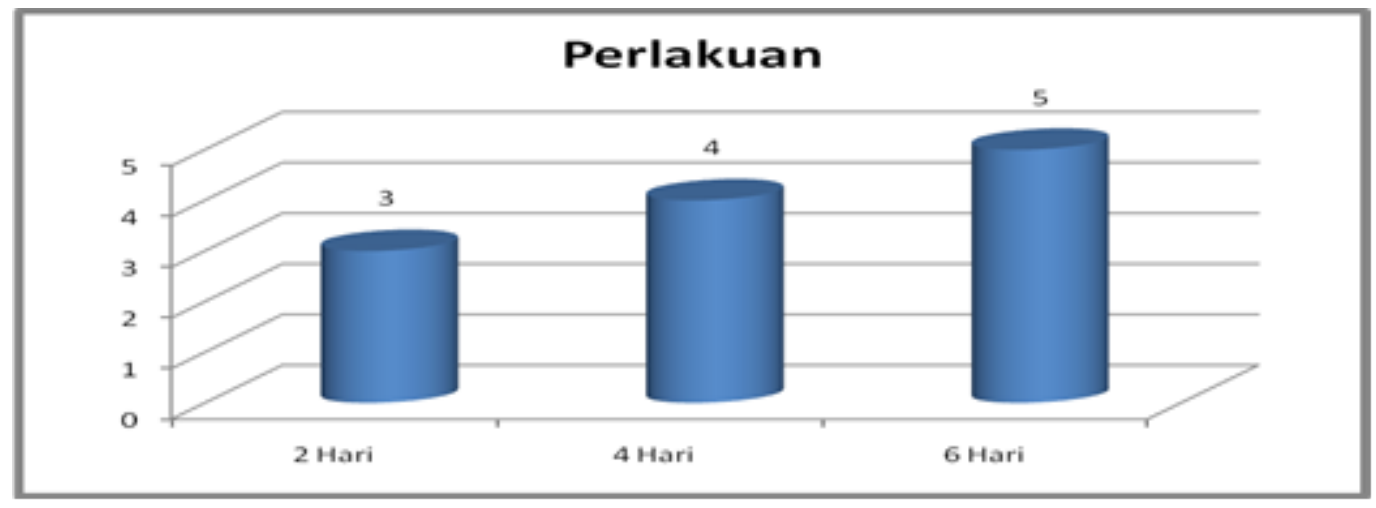

Gambar 4 Histogram jumlah rata-rata hasil tangkapan bubu setiap perlakuan

Berdasarkan gambar histogram, dapat terlihat jelas jumlah rata-rata hasil tangkapan bubu apung tiap perlakuan, di mana perlakuan pertama menggunakan bubu apung dengan lama perendaman 2 hari dengan jumlah rata-rata hasil tangkapan 3 ekor dari tiga kali ulangan, dan perlakuan kedua dengan lama perendaman 4 hari dengan jumlah rata-rata hasil tangkapan 4 ekor dari tiga kali ulangan, sedangkan perlakuan ke tiga dengan lama perendaman 6 hari dengan jumlah rata-rata hari tangkapan 5 ekor dari tiga kali ulangan. 


\section{Indikator Hasil Tangkapan Utama dan Hasil Tangkapan Sampingan}

Berdasarkan dari hasil penelitian, maka hasil tangkapan bubu dikelaskan ke dalam dua kelompok yaitu, hasil tangkapan utama dan hasil tangkapan sampingan seperti pada Tabel 7.

Tabel 7 Pengelompokan ikan berdasarkan kategori

\begin{tabular}{lc}
\hline \multicolumn{2}{c}{ Hasil Tangkapan } \\
\hline \multicolumn{1}{c}{ Ikan Hasil Tangkapan Utama } & Ikan Hasil Tangkapan Sampingan \\
\hline Baronang & Jarang gigi \\
Ikan Tanda-tanda & \\
\hline
\end{tabular}

\section{Indikator Panjang Hasil Tangkapan Bubu Apung}

Hasil tangkapan bubu apung yang didapat dari tiap unit percobaan diukur untuk mengetahui panjang dari hasil tangkapan bubu apung yang telah dioperasikan di perairan Labuhan Angin yang tertera pada Tabel 8.

Tabel 8 Indikator panjang hasil tangkapan ikan tanda-tanda

\begin{tabular}{lrrrr}
\hline \multirow{2}{*}{ Perlakuan } & \multicolumn{4}{c}{ Panjang Ikan $(\mathrm{cm})$} \\
\cline { 2 - 5 } & DP 1 & \multicolumn{3}{c}{ DP 2 } \\
\hline 2 hari & 18 & 16 & 21 \\
4 hari & 17 & 35 & 34 \\
6 hari & 35 & 35 & 40 \\
Rata-rata & & 28,66 & 31,66
\end{tabular}

Berdasarkan data penelitian di atas menunjukan bahwa ada keragaman panjang hasil tangkapan dari setiap perlakuan dan daerah penangkapan ikan. Sebaran data panjang hasil tangkapan dituangkan dalam histogram di bawah ini.

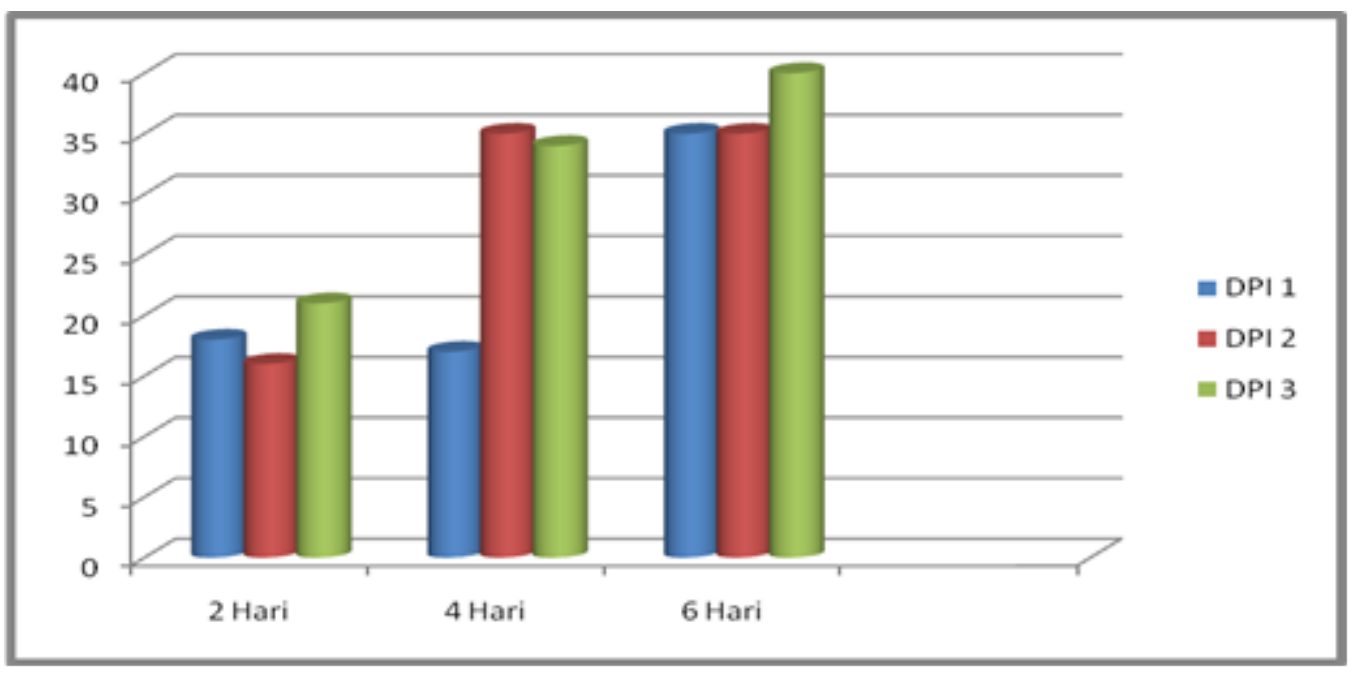

Gambar 5 Histogram panjang hasil tangkapan bubu apung

Gambar histogram di atas menunjukkan bahwa pada perlakuan perendaman selama 6 hari menunjukan total panjang ikan lebih besar disebabkan jumlah hasil tangkapan pada lama perendaman 6 hari yang lebih banyak dari perlakuan lainnya.

\section{KESIMPULAN DAN SARAN}

Penggunaan bubu apung sangat ramah lingkungan. Bubu apung tidak akan merusak terumbu karang sebagai habitat ikan karena bubu tidak menempel pada terumbu karang. Hasil tangkapan yang 
diperoleh berjumlah 37 ekor dengan hasil tangkapan terbesar pada perlakuan ke 3 dengan lama perendaman 6 hari sebanyak 15 ekor. Jenis hasil tangkapan adalah ikan tanda (Lutjanus Mahogoni), ikan baronang (Siganus sp.), dan ikan jarang gigi (Lutjanus argentimaculatus). Untuk mendapatkan hasil tangkapan yang maksimal dibutuhkan atraktor sebagai daya pikat ikan.

\section{UCAPAN TERIMA KASIH}

Kami mengucapkan terima kasih yang sebesar-besarnya kepada Kementerian Pendidikan dan Kebudayaan Dirjen DIKTI Riset dan Teknologi, dukungan berupa dana penelitian untuk menyelesaikan penelitian ini. Ucapan terima kasih juga kami sampaikan kepada Sekolah Tinggi Perikanan Sibolga, beserta LPPM di dalamnya sebagai instansi dan lembaga yang menfasilitasi penelitian kami hingga selesai.

\section{DAFTAR PUSTAKA}

Aslan LM dan Nadia LOAR. 2010. Potret Masyarakat Pesisir Sulawesi Tenggara. Unhalu Press. Kendari.

Daeli, Maximilia, Juni Susanti Banurea. 2020. Analisis Kebijakan Perikanan Tangkap Terhadap Hasil Tangkapan Nelayan Tradisional Kota Sibolga. Jurnal Penelitian Terapan Perikanan dan Kelautan 2 (2): 96-103.

Hefraris. 2020. Komposisi Hasil Tangkapan Bubu Kawat Nelayan Desa Ujung Tanjung Kecamatan Tanah Putih Kabupaten Rokan Hilir Provinsi Riau. [Skripsi]. Universitas Riau. Pekanbaru. 58 Hlm.

Isnawati, La Anadi, Abdullah. 2020. Pengaruh Lama Perendaman Bubu Terhadap Hasil Tangkapan Ikan Di Perairan Tondonggeu Kecamatan Abeli Kota Kendari Sulawesi Tenggara. Jurnal Manajemen Sumber Daya Perairan 6(1): 83-90.

Kesaulya, Taufiniringsi, Delly DP, Matrutty M. 2015. Arah Penempatan Mulut Bubu Terhadap Hasil Tangkapan Ikan Di Perairan Dusun Mamua Kecamatan Leihitu Maluku Tengah. Jurnal Amanisal PSP Unpatti FPIK Unpatti. Ambon 4(1): 24-31.

Martasuganda S. 2008. Bubu (Traps). Cetakan ketiga. Serial Teknologi Penangkapan Ikan Berwawasan Lingkungan. Institut Pertanian Bogor. IPB Press. Bogor.

Munirma, Ma'ruf Kasim, Nur Irawati, Halili, Salwiyah, La Ode Abdul Rajab Nadia. 2020. Studi Produktivitas Primer Fitoplankton di Perairan Danau Motonuno Desa Lakarinta Kecamatan Lohia Kabupaten Muna. Jurnal Manajemen Sumberdaya Perairan 5(1): 8-16.

Nasrudin Thoha. 2016. Strategi Bertahan Hidup Nelayan Angin-angin Kecamatan Wedung Kabupaten Demak. [Skripsi]. UIN Sunan Kalijaga. Yogyakarta. $38 \mathrm{Hlm}$.

Noer Justiar. 2011. Perikanan Bubu Dasar di Kabupaten Bangka Selatan, Provinsi Kepulauan Bangka Belitung. (Tesis). Bogor. Fakultas Perikanan dan Ilmu Kelautan. Institut Pertanian Bogor. Bogor.

Peraturan Menteri Kelautan dan Perikanan Republik Indonesia (PERMEN KP) Nomor 26. 2021. Tentang Pencegahan Pencemaran. Pencegahan Kerusakan, Rehabilitasi, dan Peningkatan Sumber Daya Ikan dan Lingkungannya.

Puspito G. 2009. Perangkap Non-Ikan. Departemen Pemanfaatan Sumberdaya Perikanan Fakultas Perikanan dan Ilmu Kelautan. Institut Pertanian Bogor.

Setiyono E. 2016. Perbandingan Lama Perendaman Bubu Dasar Menggunakan Tutupan Daun Kelapa Terhadap Hasil Tangkapan Ikan di Teluk Kelabat Desa Pusuk. Fakultas Pertanian, Perikanan dan Biologi, Universitas Bangka Belitung 10(2): 1-5. 
Sitinjak Ladestam, Henry Sinaga. 2021. Pengembangan Budidaya Ikan Hias Air Laut Dengan Penggunaan Biofilter Pada Sistem Resirkulasi. Albacore: Jurnal Penelitian Perikanan Laut 4(2): 133-139.

Sudjana. 2018. Desain dan Analisis Eksperimen. Edisi II. Tarsito. Bandung.

Von Brandt, A. 2005. Classification of Fishing Gear. In Kristjonsson (Ed), Modern Fishing Gear of the World. Fishing News (Books) Ltd.London. 